\title{
The Role of Social Factors in Iranian University Students' Predispositions towards Autonomous Language Learning
}

\author{
Sara Kashefian Naeeini, Abdolmehdi Riazi, and Hadi Salehi \\ (Shiraz University, Iran) \\ doi:10.7575/aiac.alls.v.3n.2p.41
}

\begin{abstract}
In order to meet the demands of the changing world, students should become endowed with the ability to learn perpetually and regard learning as a life-long enterprise. This study investigated those learner beliefs which showed learners' predispositions towards autonomy and some social factors such as gender, academic achievement, marital status and age were taken into consideration. All BA and MA students majoring in English Literature at the department of Foreign Languages of Shiraz University of Iran were involved. The data were collected through a questionnaire the items of which were obtained from two questionnaires by Cotterall (1995) and Cotterall (1999) which were incorporated into a five-point Likert-type rating scale. Factor analysis of responses of students revealed the existence of five underlying factors for learner autonomy which were learner independence, dependence on the teacher, learner confidence, attitudes towards language learning and self-assessment. Based on t-test for independent samples and Analysis of Variance it came to light that age and gender did not have impact on students' readiness for autonomy while marital status influenced students' self-assessment. Moreover, good academic achievement positively influenced their predispositions towards autonomous language learning.
\end{abstract}

\section{Introduction}

Learning is a process which extends throughout a person's life; accordingly, every person should strive to foster autonomy in order to make growing progress. Kenny (1993) affirms that autonomy is a vital concept for education, for it is the only aspect of a learner's being upon which education can focus without harmful interference, or conditioning effects. What education is about is empowerment and what education empowers is a person's autonomy. This study aimed to compare different views about autonomy and empowerment, to discuss some of the aspects of learner autonomy and to shed light on the Autonomous Learning Modules (ALMS) and those aspects revealed by the ALMS. 
The study intended to find answers to the following questions:

1) Does the age of students play any role in their readiness for autonomy and the underlying factors of autonomy?

2) Are married students different from single students in their readiness for autonomy and the underlying factors of autonomy?

3) Are male and female students different in their readiness for learner autonomy and the underlying factors of autonomy?

4) Do students' GPAs as indexes of their academic achievement influence their readiness for autonomy and the underlying factors?

\section{Autonomy and empowerment}

One of the goals of education is empowerment and one of the upshots of autonomous language learning is empowering students with the ability to learn for life. As Simon (1987) declared, empowerment is enabling those who have been silenced to speak. Likewise, he maintained that empowerment is the opportunity and means to effectively participate and share authority.

Fitzgerald, Morrall and Morrison (1996) also indicated that to facilitate personal development learners have to take a pro-active role in the learning process. Rubin (1975) confirmed that many language teachers fail to attend to the learning process and provided that they pay more attention, they may be able to supply the students with some techniques which can enable them to learn on their own.

\section{The Autonomous Learning Modules (ALMS)}

The ALMS of the Helsinki University Language Center underscores autonomous approaches to language learning. As Sirvio (1998) declared, the ALMS were based on a task-based learning model, where student-centered approach and the concept of "learning to learn" are the key elements. The ALMS was first implemented in the learning of English as a second language at the university level.

As Karlsson, Kjisik, and Norlund (1996) confirmed, in the project students were perceived as thinking human beings with different needs, skills and motivations. Students were given more control over what, when, how and where they learned. The changes in attitude were in a 
positive direction. There was a general improvement in motivation and students discovered that learning could be fun and useful. They had a realization that they were empowered for life and that they themselves had control over what and whether they learned. There was also a growth in their awareness that affected other domains in their life. The success or failure of an individual student or teacher working in an autonomous setting rests largely on their attitudes.

\section{Ten aspects of autonomy revealed by the ALMS}

In 1997, Karlsson, Kjisik and Nordlund (1996) offered ten aspects of autonomy which were determined via the Autonomous Learning Modules Project of the Helsinki University Language center.

1. Autonomy is a capacity that has to be learned.

2. The road to autonomy is a process.

3. The state of autonomy is essentially unstable.

4. Autonomy involves a change in the power relationships.

5. Autonomy requires supportive structures, both internal and external.

6. Autonomy requires a conscious awareness of the learning process.

7. Autonomy has both individual and social aspects.

8. Autonomy is not limited to the classroom.

9. Autonomy has to be adapted to different cultural contexts.

10. Autonomy is closely related to social identity.

\section{Some of the dimensions of learner autonomy}

\section{Self-direction}

Lee (1998) implemented a self-directed learning program for tertiary students in Hong Kong and found that self-directed learning paves the way for students' development of autonomy. She contended that her self-directed learning program was more successful with those students who demonstrated some degree of autonomy in learning. She reported that learner autonomy and self-directed learning were increasingly associated with social and collaborative learning.

Lee's self-directed learning program showed that the more enthusiastic students enjoyed selfdirected learning and wanted to continue independent learning after the course. Kohonen 
(1999) affirmed that in terms of the conception of man, learners needed to be considered as self-directed, intentional persons who could develop their competencies in three interrelated areas of knowledge, skills and awareness.

\section{Learner control}

One of the characteristics of autonomous learners is that they are more inclined to exercise more control with regard to their learning. Dickinson (1993) asserted that when learners were in control of their learning, they were exercising autonomy and one aspect of the control was in the area of assessment. Warshauer, Turbee and Roberts (1996) argued that a main goal of modern approaches to language teaching is to enhance student autonomy and learner control over the learning process. Fayard (1999) stated that control reduced learner passivity, increased receptivity to language and boosted the self-confidence of learners.

Learner control is an important issue in language learning. Successful language learners can perceive themselves in control of their learning (Dickinson, 1995). In his article, Nishkura (1997) mentioned control and responsibility, intrinsic motivation and self-generated behavior as some of the main characteristics of successful language learners. Nishikura claimed that the use of concept of "control" could provide a framework from which learning interaction takes place.

\section{The present study}

All male and female B.A. and M.A. students majoring in English Literature in the Department of Foreign Languages and Linguistics of Shiraz University were involved in the present study. Participants were from two levels of education referred to here as undergraduate (B.A. students) and graduate (M.A. students). On the whole, 168 students (53 males and 115 females) participated in the study. They differed with regard to their age and marital status. Tables 1 and 2 present the composition of students from different age groups and different marital status.

Table 1: Composition of students considering age

\begin{tabular}{ccc}
\hline Age Group & Frequency & Percent \\
\hline $18-21$ & 86 & 51.2 \\
$22-25$ & 65 & 38.7 \\
26 and over & 17 & 10.1 \\
\hline
\end{tabular}


Table2: Composition of students regarding marital status

\begin{tabular}{lcc}
\hline Marital Status & Frequency & Percent \\
\hline Single & 131 & 78 \\
Married & 35 & 20.8 \\
Unanswered & 2 & 1.19 \\
\hline
\end{tabular}

Table 3: Composition of participants regarding sex

\begin{tabular}{lcc}
\hline Sex & Frequency & Percent \\
\hline Male & 53 & 31.5 \\
Female & 115 & 68 \\
\hline
\end{tabular}

Table 4: Composition of students regarding GPA

\begin{tabular}{lcc}
\hline GPA & Frequency & Percent \\
\hline $17-20(\mathrm{~A})$ & 79 & 47 \\
$14-16.99(\mathrm{~B})$ & 76 & 45.2 \\
$12-13.99(\mathrm{C})$ & 11 & 6.5 \\
Unanswered & 2 & 1.19 \\
\hline
\end{tabular}

*In Iranian universities students are evaluated according to a scale which runs from 0 to 20 . An academic average of 17 to 20 which is considered as an A average, while an average between 14-16.99 is evaluated as B and one in the range of 12 to 13-99 out of 20 is deemed as $\mathrm{C}$.

The necessary data were collected via a questionnaire the items of which were taken from two other questionnaires by Cotterall (1995) and Cotterall (1999) with some adaptations. The questionnaire was in the form of a five-point Likert-type rating scale.

The questionnaire was administered to all B.A. and M.A. students majoring in English Literature in the Department of Foreign Languages and Linguistics in Shiraz University. About 182 students received the questionnaire and they were provided enough time to complete it. From 182 questionnaires administered to the students, 168 (92.3\%) were returned to the researcher.

Factor Analysis was also performed which served not only to confirm the validity of the questionnaire but also to find the underlying factors of autonomy. Based on factor analysis, five underlying factors were extracted. These factors were learner independence, dependence on the teacher, learner confidence, attitudes towards language learning and self-assessment. 


\section{Results}

When the means of students of different age groups were compared and the one-way ANOVA was applied, it was found that the differences in means were not statistically significant for any of the factors of learner independence, dependence on teachers, learner confidence, attitudes towards language learning and self-assessment (See Appendix A for means and standard deviations of students and the one way ANOVA for the five factors by age).

In order to obtain a measure of autonomy for students of each age group, a one-way ANOVA was run and the means of students of different age groups were compared. Although students of the age group 18-21 had the highest mean (129.81), the differences were not statistically significant.

Table 5: Means and standard deviations of students of different age groups considering learner autonomy

\begin{tabular}{lll}
\hline Age & Mean & SD \\
\hline $18-21$ & 129.81 & 12.63 \\
$22-25$ & 126.53 & 12.29 \\
26 and over & 126.23 & 18.57 \\
Total & 128.18 & 13.23 \\
\hline
\end{tabular}

Table 6: One-way ANOVA for learner autonomy by age

\begin{tabular}{llllll}
\hline Source of Variance & df & Sum of Squares & Mean Square & F & P \\
\hline Between Group & 2 & 469.04 & 234.52 & 1.34 & .2634 \\
Within Group & 165 & 28770.23 & 174.36 & & \\
Total & 167 & 29239.27 & & & \\
\hline
\end{tabular}

Those students who were single received higher means in all factors except attitudes towards language learning for which married students obtained higher means. The differences in means were significant regarding self-assessment at the .03 level. In light of learner independence, dependence on the teacher, learner confidence and attitudes towards language learning the differences were not significant. It can be argued that the concept of self is not probably as much important to a married person as it is to a single one. Single students usually have more time to ponder over and to assess their learning experiences. 
Table 7: Comparison of participants with different marital status considering the 5 factors

\begin{tabular}{|c|c|c|c|c|c|c|c|}
\hline Factors & $\begin{array}{l}\text { Mean } \\
\text { (Sing.) }\end{array}$ & $\begin{array}{l}\text { Mean } \\
\text { (Mar.) }\end{array}$ & $\begin{array}{l}\text { SD } \\
\text { (Sing.) }\end{array}$ & $\begin{array}{l}\text { SD } \\
\text { (Mar.) }\end{array}$ & t-value & df & 2-Tail Sig \\
\hline $\begin{array}{l}\text { Learner } \\
\text { Independence }\end{array}$ & 41.77 & 39.40 & 8.61 & 7.49 & 1.61 & 164 & .131 \\
\hline $\begin{array}{l}\text { Dependence } \\
\text { on Teacher }\end{array}$ & 26.28 & 25.97 & 3.19 & 3.98 & .46 & 164 & .650 \\
\hline $\begin{array}{l}\text { Learner Confidence } \\
\text { Attitudes } \\
\text { towards } \\
\text { Language Learning }\end{array}$ & $\begin{array}{l}28.13 \\
14.25\end{array}$ & $\begin{array}{l}27.49 \\
15.09\end{array}$ & $\begin{array}{l}4.40 \\
3.42\end{array}$ & $\begin{array}{l}4.36 \\
3.47\end{array}$ & $\begin{array}{l}.77 \\
1.27\end{array}$ & $\begin{array}{l}164 \\
164\end{array}$ & $\begin{array}{l}.442 \\
.211\end{array}$ \\
\hline Self-assessment & 18.58 & 17.51 & 2.28 & 2.58 & 2.23 & 164 & .030 \\
\hline
\end{tabular}

The t-test showed that those students who were single obtained higher means in learner autonomy (129) in comparison with that of the married ones. Nevertheless, the difference was not significant.

\section{Table 8: Comparison of married and single students considering learner autonomy}

\begin{tabular}{llllll}
\hline Marital Status & Mean & SD & df & t-value & Level of Sig \\
\hline Single & 129 & 13.28 & & & \\
Married & 125.45 & 13.12 & 164 & 1.42 & .16 \\
\hline
\end{tabular}

The means of males and females were compared using t-test for independent samples and it was found that females obtained slightly higher means regarding the factors of learner independence, dependence on teachers, learner confidence, and self-assessment and males received a higher mean with regard to attitudes towards language learning. However, the differences did not turn out to be significant as presented in the table.

Table 9: Comparison of means of males and females considering the 5 factors

\begin{tabular}{llllllll}
\hline Factors & $\begin{array}{l}\text { Mean } \\
(\text { Male) }\end{array}$ & $\begin{array}{l}\text { Mean } \\
\text { (Female) }\end{array}$ & $\begin{array}{c}\text { SD } \\
(\text { Male) }\end{array}$ & $\begin{array}{c}\text { SD } \\
\text { (Female) }\end{array}$ & t-value & df & 2-Tail Sig \\
\hline Learner Independence & 40.81 & 41.46 & 8.81 & 8.19 & .45 & 166 & .651 \\
& & & & & & & \\
Dependence on Teacher & 25.68 & 26.41 & 2.87 & 3.45 & 1.45 & 166 & .149 \\
& 27 & 28.44 & 4.76 & 4.10 & 1.91 & 166 & .060 \\
Learner Confidence & 14.72 & 14.25 & 2.87 & 3.21 & .76 & 166 & .448 \\
$\begin{array}{l}\text { Attitudes towards } \\
\text { Language Learning }\end{array}$ & & & & & & & \\
Self-assessment & 18.23 & 18.42 & 2.87 & 2.10 & .43 & 166 & .665 \\
\hline
\end{tabular}


The means of males and females as indexes of autonomy were compared. Although females had a higher mean (128.99), the difference was not statistically significant. The results are shown in the following table.

Table 10: Comparison of males and females considering learner autonomy

\begin{tabular}{llllll}
\hline Sex & Mean & SD & df & t-value & Level of Sig \\
\hline Male & 126.43 & 15.64 & & & \\
Female & 128.99 & 11.94 & 166 & 1.06 & .29 \\
\hline
\end{tabular}

In order to obtain a general index of learner autonomy of students with different GPAs, a oneway ANOVA was carried out and the comparison of means showed that the differences in means were statistically significant at .0051 level and the students whose averages were in the range 17-20 had the highest mean.

Table 11: The Means and SDs of students with different gpas considering learner autonomy

\begin{tabular}{lll}
\hline GPA (Out of 20) & Mean & SD \\
\hline $17-20(\mathrm{~A})$ & 131.41 & 10.56 \\
$14-16.99(\mathrm{~B})$ & 125.48 & 14.66 \\
$12-13.99(\mathrm{C})$ & 122.25 & 14.07 \\
Total & 128.18 & 13.23 \\
\hline
\end{tabular}

Table 12: One-way ANOVA for Learner Autonomy by GPA

\begin{tabular}{llllll}
\hline $\begin{array}{l}\text { Source of } \\
\text { Variance }\end{array}$ & df & $\begin{array}{l}\text { Sum of } \\
\text { Squares }\end{array}$ & Mean Square & F & P \\
\hline Between Group & 2 & 1798.94 & 899.47 & 5.46 & .0051 \\
Within Group & 164 & 27004.45 & 164.66 & & \\
Total & 166 & 28803.40 & & & \\
\hline
\end{tabular}

The results of the Scheffe Test are depicted here. It was found that the means of the first group (students with an average range of A) and those of the third group (students with an average C) were significantly different at .05 level.

Table 13: The Results of the Scheffe Test for learner autonomy by GPA

\begin{tabular}{lllll}
\hline Mean & Group & $\mathbf{1}$ & $\mathbf{2}$ & $\mathbf{3}$ \\
\hline 131.41 & 1 & & & $*$ \\
125.48 & 2 & & & \\
122.25 & 3 & & & \\
\hline
\end{tabular}

\section{Summary and conclusion}

The present study intended to compare different views about autonomy and empowerment, to discuss some of the aspects of learner autonomy and to shed light on the Autonomous 
Learning Modules (ALMS) and those aspects revealed by the ALMS. It mainly aimed at examining the role of age, marital status, gender and academic achievement in students' predispositions towards autonomy. Factor analysis of responses was run and five underlying factors were identified. These underlying dimensions were learner independence, dependence on the teacher, learner confidence, attitudes towards language learning and self-assessment. Though index of autonomy proved to be highest for students who were in the age range of 18.64 and lowest for students in the age range of 26 and over, the differences were not statistically significant. It can be concluded that the age of students does not influence their predispositions towards autonomy. Single students obtained a higher score in self-assessment; however, the differences did not turn out to be significant considering learner autonomy. Students' academic achievement affects to a great extent their predispositions towards autonomy in that those students with an average of A demonstrated a great deal of autonomy while those students who had an average of $\mathrm{C}$ showed the lowest index of autonomy. Though index of autonomy was higher for females, the differences were not statistically significant. In other words, gender does not have impacts on students' readiness for autonomy. By and large, it can be noted that autonomy is a desired capacity which should be inculcated in the minds of all learners.

\section{References}

Cotterall, S. (1995b). Readiness for autonomy: Investigating learner beliefs. System, 23(2), 196-205.

Cotterall, S. (1999). Key variables in language learning: What do learners believe about them? System, 27(1), 493-513.

Dickinson, L. (1993). Talking shop: Aspects of autonomous learning, ELT Journal, 47(4), 330-336.

Dickinson, L. (1995). Autonomy and motivation: A literature review. System, 23(2), 165-174.

Fitzgerald, S., Morrall, A., \& Morrison, B. (1996). Catering for individual learning styles. Experience of orienting students in an Asian self-access center. Paper presented at the conference of Autonomy 2000, Bangkok, Thailand.

Karlsson, L., Kjisik, F., \& Nordlund, J. (1996). The Autonomous Learning Project. Finland, Helsinki: The Helsinki University Language Center.

Karlsson, L., Kjisik, F., \& Nordlund, J. (1996). From Here to Autonomy. Yliopistopaino: Helsinki

Kenny, B. (1993). For more autonomy. System,21(4), 431-442.

Kohonen, V. (1999). Authentic assessment as an integration of language learning, teaching, evaluation and the teacher's professional growth. The University of Tampere, Tampere, Finland.

Lee, I. (1998). Supporting greater autonomy in language learning. ELT Journal, 52(4), 282-283.

Nishikura, H. (1997). Learner Control (EMC 730). Arizona, Tempere: Arizona State University.

Rubin, J. (1975).What the "good language learner" can teach us. TESOL Quarterly, 9(1), 41-51.

Simon, R.I. (1987). Empowerment as a pedagogy of possibility. Language Arts, 64(40), 370383.

Sirvio, P. (1998, June). New learning environments: After language Lab -multimedia, after multimedia - ...? Paper presented at the conference of From Bayeux to Multimedia, Leksand's Gymnasium, University of Art and Design, Helsinki, Finland.

Warshauer, M., Turbee, L., \& Roberts, B. (1996). Computer Learning networks and student empowerment. System, 24(1),1-14. 


\section{Appendix A:}

Means and standard deviations of students of different age groups considering learner independence

\begin{tabular}{lll}
\hline Age & Mean & SD \\
\hline $18-21$ & 42.29 & 8.87 \\
$22-25$ & 40.20 & 7.11 \\
26 and over & 40.05 & 9.96 \\
Total & 41.25 & 8.37 \\
\hline
\end{tabular}

One-way ANOVA for factor 1 by age

\begin{tabular}{llllll}
\hline $\begin{array}{l}\text { Source of } \\
\text { Variance }\end{array}$ & df & $\begin{array}{l}\text { Sum of } \\
\text { Squares }\end{array}$ & Mean Square & F & P< \\
Between Group & 2 & 188.92 & 94.46 & 1 & .35 \\
Within Group & 165 & 11521.07 & 69.82 & & \\
Total & 167 & 11709.99 & & & \\
\hline
\end{tabular}

Means and standard deviations of students of different age groups considering dependence on the teacher

\begin{tabular}{lll}
\hline Age & Mean & SD \\
\hline $18-21$ & 26.03 & 3.28 \\
$22-25$ & 26.44 & 3.27 \\
26 and over & 25.94 & 3.69 \\
Total & 26.18 & 3.28 \\
\hline
\end{tabular}

One-way ANOVA for factor 2 by age

\begin{tabular}{cccccc}
\hline $\begin{array}{c}\text { Source of } \\
\text { Variance }\end{array}$ & df & Sum of Squares & Mean Square & F & P< \\
\hline Between Group & 2 & 7.38 & 3.69 & 0.33 & .71 \\
Within Group & 165 & 1795.89 & 10.88 & & \\
Total & 167 & 1803.27 & & & \\
\hline
\end{tabular}

Means and standard deviations of students of different age groups considering their learner confidence

\begin{tabular}{ccc}
\hline Age & Mean & SD \\
\hline $18-21$ & 28.73 & 4.31 \\
$22-25$ & 27.30 & 3.89 \\
26 and over & 26.82 & 5.68 \\
Total & 27.98 & 4.35 \\
\hline
\end{tabular}


One-way ANOVA for factor 3 by age

\begin{tabular}{cccccc}
\hline $\begin{array}{l}\text { Source of } \\
\text { Variance }\end{array}$ & df & Sum of Squares & Mean Square & F & P \\
\hline Between Group & 2 & 100.81 & 50.40 & 2 & .7098 \\
Within Group & 165 & 30.96 & 18.60 & & \\
Total & 167 & 31.69 & & & \\
\hline
\end{tabular}

Means and standard deviations of students of different age groups considering attitudes towards language learning

\begin{tabular}{ccc}
\hline Age & Mean & SD \\
\hline $18-21$ & 14.11 & 3.33 \\
$22-25$ & 14.49 & 3.26 \\
26 and over & 15.47 & 4.41 \\
Total & 14.39 & 3.42 \\
\hline
\end{tabular}

One-way ANOVA for factor 4 by age

\begin{tabular}{cccccc}
\hline $\begin{array}{c}\text { Source of } \\
\text { Variance }\end{array}$ & df & Sum of Squares & Mean Square & F & $\mathbf{P}<$ \\
\hline Between Group & 2 & 26.96 & 13.48 & 1 & .1481 \\
Within Group & 165 & 1937.31 & 11.74 & & \\
Total & 167 & 19.64 & & & \\
\hline
\end{tabular}

One-way ANOVA for factor 5 by age

\begin{tabular}{llllll}
\hline $\begin{array}{l}\text { Source of } \\
\text { Variance }\end{array}$ & df & Sum of Squares & Mean Square & F & P< \\
\hline Between Group & 2 & 14.36 & 7.17 & 1 & .2873 \\
Within Group & 165 & 920.21 & 5.57 & & \\
Total & 167 & 934.57 & & & \\
\hline
\end{tabular}

